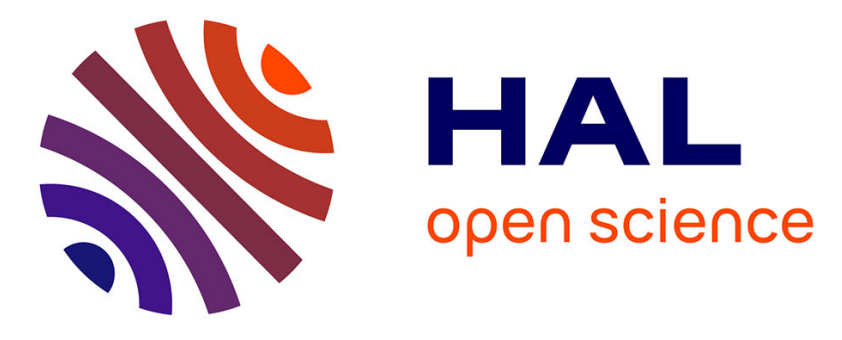

\title{
Framing Power: Tracing Key Discourses in Open Science Policies
}

Denisse Albornoz, Maggie Huang, Issra Marie Martin, Maria Mateus, Aicha Yasmine Touré, Leslie Chan

\section{- To cite this version:}

Denisse Albornoz, Maggie Huang, Issra Marie Martin, Maria Mateus, Aicha Yasmine Touré, et al.. Framing Power: Tracing Key Discourses in Open Science Policies. ELPUB 2018, Jun 2018, Toronto, Canada. 10.4000/proceedings.elpub.2018.23 . hal-01816725

\section{HAL Id: hal-01816725 https://hal.science/hal-01816725}

Submitted on 15 Jun 2018

HAL is a multi-disciplinary open access archive for the deposit and dissemination of scientific research documents, whether they are published or not. The documents may come from teaching and research institutions in France or abroad, or from public or private research centers.
L'archive ouverte pluridisciplinaire HAL, est destinée au dépôt et à la diffusion de documents scientifiques de niveau recherche, publiés ou non, émanant des établissements d'enseignement et de recherche français ou étrangers, des laboratoires publics ou privés.

\section{(c)(1)}

Distributed under a Creative Commons Attribution| 4.0 International License 


\title{
Framing Power: Tracing Key Discourses in Open Science Policies
}

\author{
Denisse Albornoz, Maggie Huang, Issra Marie Martin, Maria Mateus, \\ Aicha Yasmine Touré and Leslie Chan
}

We would like to thank Swaraj Paul Barooah of the Centre for Internet and Society India for his detailed review of this piece.

1 As Open Science picks up momentum among scientists and policymakers, the question of how and why Open Science should be practiced continues to be subject of debate. The textbook definition of Open Science refers to the set of practices designed to open up and increase participation across the scientific lifecycle, in order to provide greater accessibility to scientific knowledge, promote the development of alternative impact metrics and the use of collaborative research infrastructures, among other characteristics (Bartling, S. \& Friesike S., 2014, Nielsen, M., 2013; Fecher B., and Friesike S., 2013., Mayer, 2015). Critical schools of thought have added to this definition that a more collaborative science can also create opportunities to redress global historical injustices in scientific production by facilitating the meaningful participation of formerly excluded social and political actors and promoting the co-production of knowledge to address sustainable development goals (Hillyer et al, 2017; Albornoz et al, 2017; Okune et al, 2016, Moletsane, 2015). The term has also become a popular policy object, as it steadily gains traction in international and national science and technology programs. However, the assumptions and values represented in these policies remain unclear.

2 This study intends to identify key narratives about Open Science in public policy-which are produced, reproduced and by whom, and in turn whose interests are neglected in this process. It seeks to contribute to the body of scholarship that investigates the modalities and impact of Open Access and reveals how uncritical narratives of "openness", far from redressing structural barriers to knowledge production in science, are in fact bolstering the visibility and over-representation of knowledge produced by dominant groups (Schopfel and Herb, 2018; Lawson, 2017, Moore, 2017, El Sabry, 2016, Okune, 2016). These findings highlight the wide disconnect between narratives of "openness" that promise the equitable democratization of knowledge and their use by well-resourced higher 
education institutions and commercial publishers to commercialize knowledge and in the words of Stuart Lawson, sustain "the very systems it was meant to challenge" (Lawson, 2017, Neylon, 2017, Mayer, 2015).

This paper will first conceptualize policy as instruments of "epistemic governance"-the notion that knowledge-related paradigms, values and norms are embedded in policies, which are in turn used to exert power and influence over relevant stakeholders. It will then explain the methodology used to identify the key norms and values present in the framing of Open Science in policies. This will be followed by an overview of the key narratives identified in the data, to then offer a discussion on what these frames tell us about how power is being negotiated and resources being mobilized in and through the concept of Open Science. It will close by reflecting on the need to situate Open Science narratives in the context of global inequality in scientific knowledge production and a call to remain critical of the patterns of domination and dependency that are reproduced through technological trends in scientific production.

\section{Policy as Tools of Epistemic Governance}

4 The ideas that prevail in policy-making processes have the power to influence how resources are channeled, what programs are implemented, and the meanings we attribute to issues of public interest (Alasuutari \& Qadir, 2010). In this way, public policies are instruments of what has been dubbed "epistemic governance": the notion that knowledge-related paradigms underlie social systems, and therefore, sustain governance models. Epistemic governance posits that global governance is in large part built on processes of knowledge production and transfer negotiated by stakeholders who belong to and represent a set of interests, relationships and institutional demands (Alasuutari \& Qadir, 2010, Buduru and Pal 2010). Under this notion, policies are not neutral, but speak to and evoke these actors' deep-seated values, beliefs and paradigmatic assumptions (Alasuutari \& Qadir, 2010; Alasuutari, 2010). Social movement scholars have also investigated the process of articulation and negotiation of ideas by looking at "frame mobilization": how actors communicate their ideals and how they persuade their allies to achieve a set of goals and influence collective action. (Kapczynski, 2008, Benford \& Snow, 2002, Alasuutari \& Qadir, 2010). Alliance building and collective mobilization in these negotiations go hand-in-hand with building consensus on "what is considered virtuous and acceptable", and "what needs to be done on the basis of the current state of affairs" (Kapczynski, 2008, Alasuutari \& Qadir, 2010). Identifying the values in the narratives is therefore key to understand why Open Science is considered the "virtuous or acceptable" route for knowledge production for these actors-what is there to gain and by whom.

Revealing the underlying assumptions in the frames mobilized in governance models and instruments is key given the highly unequal nature of global relations. Processes of knowledge transfer and consensus building amongst international actors are not neutral -but rather embody the negotiation of unequal power relations that exist in global and local governance. The institutional norms, alliances and values that prevail, set new standards for governance and benchmarks for decision-making (Van Hulst \& Yanow, 2014, Benford and Snow, 2002, Mayer, 2015, Buduru \& Pal, 2010). Knowledge paradigms and benchmarks that triumph in policy are often posited as universally beneficial based on a rhetoric of "objectively" and "rigorously" defined governance indicators, leaving less powerful actors in a position in which they are "expected to calibrate their policy 
reforms" accordingly (Budaru \& Pal, 2010). Given the ideas above, this research conceives of policies as instruments that articulate paradigms that can sustain or relocate power and legitimacy. By investigating how ideas are negotiated in policy making, how they are articulated and whose interests they champion, we seek to illuminate underlying processes of epistemic negotiation in which certain set of ideas and values dominate global conversations.

\section{Methodology}

6 Following this logic, and in the context of this research, the data collection process consisted of critically investigating policies as epistemic instruments of discursive dominance. To unpack the key ideas and knowledge paradigms they represent, we sought to identify "narrative frames" or "master frames" in Open Science in policies. This process was carried out in four stages. The first stage ${ }^{1}$ involved searching for policy documents, declarations or statements from governments, and other institutions written in English, Spanish and French, with "Open Science" in the title, or with substantial Open Science references within thept of Open Science in the document, namely: definitions, characteristics, benefits of practicing content. ${ }^{2}$ The second stage involved identifying characteristic features that framed the concept Open Science, incentives to practice Open Science and main beneficiaries of Open Science. The third stage involved disaggregating the data in relation to these categories, and analyzing them transversally using content analysis methods to identify patterns, similarities and contrasts in the narratives used across regions and institutions. ${ }^{3}$

\section{Results: Dominant Frames in Open Science Policies}

\section{Who is Shaping the Open Science Agenda}

7 In total, we reviewed 49 policies, documents, declarations and statements referencing open science. ${ }^{4}$ Open science policies and projects have been produced by stakeholders globally, including by multilateral organisations like Unesco, the G7, and the OECD; as well as by international scientific societies, associations, and industry publishing bodies like the International Council for Science, the International Scientific Association, and the International Association of STM Publishing. The term "Open Science" appears to have the most significant uptake in Europe, with nearly half of the documents sourced produced by European stakeholders. This includes the European Commission who adopted it as an umbrella term for EU-wide research and innovation programmes as well as the government ministries of science, education, and culture in the Netherlands, Finland and Estonia have also produced their own policies, some in direct alignment and endorsement of EU policies; while many academic societies, library associations, university associations, and publishers have done similarly. In North America, open science was referenced in reports and policies by the governments of United States and Canada, in the National Institute of Health, and the Innovation Science, and Economic Development, respectively. In Asia, we found white papers and expert panel reports produced by the Japanese Ministry of Education, Culture, Sports, and Technology. ${ }^{5}$ In Latin America, government ministries of science, technology, and innovation in Colombia, Mexico, and Chile released their own national policies; while Latin-American 
repository network "La Referencia" (consisting of Argentina, Brazil, Chile, Colombia, Ecuador, México, Perú, Venezuela, and El Salvador) also produced a document on open science infrastructures. In Africa, while there were no state policies produced, there have been a number of forums and conferences co-hosted by a variety of stakeholders, including the South-African government academic ministry, the "Academy of Science of South Africa", with the participation of other university institutions like the Association of African Universities and the University of Ghana.

Several instances of international and European stakeholders can be seen, contributing via funding and partnership to open science policies and projects in Latin America and Africa. The European Union for example, has taken an interest in infrastructure, completely funding the Sci-GaIA e-infrastructure project in South Africa (who played an instrumental role in the Dakar Declaration of Open Science in Africa); and partially funding the Latin American La Referencia. Research4Life, a public-private partnership between international organizations (WHO, WIPO, among others) and publishers, can also be seen contributing to open science forums in Kenya. While African partners are involved, a significant numbers of presentations and speakers speaking at open science forums and conferences in Botswana appear to be from international organisations like FAO and the Committee on Data of the International Council for Science. While this could be indicative of foreign aid and international support, it suggests policy transfer is likely going from international and northern stakeholders towards historically more marginalised/peripheral regions.

\section{Placeholder for Open Access and Open Data}

9 We found that Open Science in policies is being defined interchangeably with or in relation to Open Access and Open Data practices. The Association of European Research Libraries ("LIBER") sees Open Access as the first step to enabling Open Science; Finland approaches Open Access and Open Data as complementary to Open Science, while Chile sees the value of Open Science as a concept but promotes Open Data practices throughout its narrative. Some placed a stronger emphasis on Open Access, such as the African Open Science Platform, Mexico, Japan, and the European Open Science Cloud, which promoted "Open Access by default", and "open-by-default" policies; while others emphasised bolstering the tools, systems and skills to practice Open Data. The European Commissionproduced Mallorca Declaration for Open Science, grants awards and funding to data and software experts; the European Open Science Cloud rewards open data practices by researchers; and the International Association of Scientific, Technical and Medical Publishers (STM) are actively creating new citation principles for data to ensure researchers who share open data get credit for their work. The FAIR data principles, which advocate for data being "findable, accessible, interoperable, and reusable" were embraced by a variety of stakeholders including the EU and STM. These examples are indicative of how even though there is a growing trend in the creation of Open Science policies, the ideas that they are promoting are not new to what has been previously posed by Open Access and Open Data policies and programs. On top of possibly reproducing the limitations of these movements as identified by critical OA scholars, this overall trend indicates that using the term Open Science is possibly more so about popularizing the term, rather than pragmatically adapting the system to open practices outside of what is comprised in OA and OD. 


\section{Quality Control through Open Science Standards}

through narratives that promote "improving quality, integrity, citability, reward systems", "quality assurance, enhancement and management", through the development of metrics and indicators for quality control and impact (See policy data sheet). The OECD policy calls for creating clear legal frameworks for the reuse of datasets at the national and international level, while the G7 communiqué calls for international standards for quality that ensures "speed and coherence" in Open Science practice. Meanwhile, STM frames itself and publishers as the "gatekeepers" that protects quality assurance standing between research and the public. There are also references to more "responsible research" and the improvement of "research integrity" via the encouragement of "best practices" in data collection, data management, research ethics, and more. While these standards may enable new forms of collaboration between the institutions and scientists who can meet them, they also risk creating new categories to exclude and invalidate knowledge that cannot meet this criteria; particularly when the actors developing the metrics involve publishers and states who have historically dominated scientific production. An example of this is the ongoing work of OpenAIRE in promoting its guidelines in national repositories around the world through training workshops to "test the quality of their repositories" and improve it through "guidelines compliance" (Bullemore, 2017). Two cases stand out in regards to their conceptualization of quality: in the Forum Report on Open Data and Open Science in Agriculture held in Kenya, quality is framed in relation to the usefulness and impact of research in its local context, while in the case of Japan's Open Science Policy, quality is framed in relation to how they ensure "fairness" of scientific and technological progress, placing a stronger emphasis on valuebased indicators.

\section{Open Science Research Infrastructures and its Architectural Design}

11 Many Open Science policies emphasize the development of research infrastructures and data repositories, particularly for the purposes of advancing open data goals. Japan framed infrastructures as "foundational platforms for sharing results and data" meant to "boost data access and reuse", while the EOSC's ability to offer "secure and seamless access... for storing, managing, and processing data from different sources" was highlighted. In Botswana, a forum report notes the country experiences "similar challenges as other African countries in terms of Open Science", including "utilising and adapting current ICT infrastructure, and building capacity to manage research data." Technical principles and conditions were also referenced to guide the architectural design and function of these research infrastructures, with calls for standards regarding data management, protocols, identifiers, metadata, and more. As part of the OpenAIRE project, the EU advocated for "increased interoperability for more global collaborations, by promoting technological alignment between regions and facilitating the exchange of good practices". An example of this is the Latin American Open Access repository aggregation service, La Referencia, which adopted OpenAIRE Guidelines to "improve global interoperability". OpenAIRE envisions Open Science architecture as "globally networked and distributed", which involves the development of tools such as the OpenAIRE Validator, a tool that "allows repositories to test their compatibility with the 
OpenAIRE guidelines". (Bullemore, 2017) Developing infrastructures also entails developing suitable governance mechanisms: the EOSC was to ensure participating parties develop a "minimal set of rigorously applied and enforced protocols" termed the "Rules of Engagement" to specify conditions which stakeholders could participate. The OECD also aspired for "consultative approaches that involve all relevant actors", while the EOSC noted its intention to be built on "community-based, lightweight, sustainable governance" based on the values of "representativity, proportionality, accountability, inclusiveness, and transparency". However, at the discursive level, it is not clear the extent to which contributions were equitable among stakeholders.

\section{Global Competitive and Collaborative Advantage via Open Science Investment}

12 Many countries framed the utility of open science as one of maintaining global competitive advantage, especially given anxieties of "falling behind" in science and technology, and the ability to contribute to the global knowledge base. The "international competitive edge", of Finland's open science and research policies was highlighted, with Europe overall framed as taking a "global leading role", with Open Science enabling them to "remain at the forefront". Simultaneously however, they expressed concern over losing this competitive advantage to countries like Japan, US, and China, given lack of High Performance Computing Infrastructure capabilities (Connected Digital Single Market Policy) which may risk outflow of innovation (EOSC) and dependency on external country facilities. Japan expressed similar sentiments, seeking to "retain its authority as a communicator on the international stage", while expressing anxieties of Japanese researchers becoming less visible and less able to participate in global research, thereby resulting in less international competitiveness given decreased awareness of their science and technology. The African Open Science Platform echoed these concerns, framing participation as benefiting local visibility and contribution to the global knowledge base. That being said, the rhetoric implied Africa was behind, referring to Open Science as a way to "remain relevant in terms of science", noting it needed to "align its scientific activities with... the rest of the world." While competition played a prominent role, aspirations for global collaboration continued with the EOSC policies calling for a "sustainable 'research data commons'", to reinforce "Open to the World" policies; and talks of a "globally networked... OS infrastructure which would enable a truly 'global and interoperable scholarly commons'". Meanwhile, EU aims to "improve linkages with neighbouring international cooperation partners outside EU... to facilitate the international dimension" of the Horizon 2020 program, while the G7 similarly advocated for infrastructures enabling data use for all users at a global scale.

\section{Growing role of private sector in Open Science}

13 A significant number of policies expressed the need for increased funding and investment in research, with the Mallorca Declaration noting this was essential to bring back funding success rates, so research can attract and maintain funding for their work. Meanwhile, the African Open Science platform suggested Open Science practises could "inform and attract potential funders" and "increase the return on investment" for their research. Most of the policies reviewed indicate that the main source of funding for Open Science 
initiatives has been thus far, primarily public. Mexico, Japan, and Finland for example outline various guidelines and conditionalities, such as open access publishing as stipulations for publicly funded research. However, public-private financing is increasing in the EU, suggesting that private stakeholders will be key players in the execution and framing of Open Science moving forward, perhaps even necessary as resource constraints may limit the potential of OS initiatives. The EU argued that "the involvement of industry (including SMEs) in the development of research infrastructures" could make them more aware of the opportunities offered by them, and "foster innovative potential" to improve these products. Publishers like STM and Elsevier have already highlighted their alignment, promoting their support to make data FAIR (STM), expressing their commitment to data sharing and more effective data use (Elsevier). The growing role of the private sector is also meant to bolster the development of technologies, which will help drive scientific progress and even societal revolution. STM for example notes the "use of technology to make science more collaborative", while Elsevier emphasises various tools to increase efficiency of search and diffusion. The G7 communique also suggests that the convergence of different technologies can be characterised as the "next production revolution", and will "transform production and society as a whole", suggesting a possible reliance on product and service developers.

\section{Core Beneficiaries of Open Science}

The academic community was unsurprisingly, the most commonly referenced beneficiary, out of all the stakeholders in Open Science. This community includes researchers, scientists, students, academics, and their associated academic institutionslibraries, academies, research organisations, etc. Business and industry also featured prominently, often in the context of innovation. The "Connected Digital Single Market" strategy for example, suggested the deployment of the European Cloud "will improve the capacity of businesses, especially SMEs and the non-tech industry, to innovate and create higher value digitised products". There were also notable references to collaboration between researchers and industry, to support "social innovation and productivity"; and for researchers to promote the advancement of knowledge, to allow "people and firms from all sectors to take full advantage of the benefits of innovation" (EOSC). The emphasis of research infrastructures also saw significant reference to the need for data scientists and technical experts, to develop competencies in open data skills, data management skills, use of infrastructure, analytics technologies, and more (Mallorca, EU Society Work Programme, FAO Kenya Report, Japan). Lastly, Open Science was commonly framed as benefiting citizens due to enhanced accessibility of research, particularly those that are publicly funded (Japan); enhanced accessibility and participation in research via more inclusive (AOSP) and diverse opportunities like "citizen science" projects (G7, OECD), for the ultimate goal of "tightening bonds between science and society" (Colciencias), improve accuracy and public trust in science overall.

\section{Challenges of involving non-experts}

15 Despite these ambitions, training citizens with the necessary skills has been noted to be a significant challenge. Colombia, Chile and the UK Royal Society noted that though the "citizen" is framed as someone essential for processes of citizen science, "their effective 
participation constitutes a challenge for shaping open agendas of research". The EU Work Programme similarly admitted "the formal integration of skills... by non academic actors and provided in non academic surroundings... will be a specific challenge"; while Japan agreed that "the increasing complexity and specialization of science and technology has made it difficult to attract understanding and support from society as a whole". This increasing complexity and specialisation in science and technology is not only an access challenge for citizens, but even for academia, where a "clash of cultures" was noted between data science and academic communities, emphasising the need for core data experts to translate opportunities. (ESOC High Level Expert Group) While participation is a laudable goal, the resources and skills required to engage with these spaces raise the question of how meaningful citizen participation can really be.

\section{Open Science as a Driver of Innovation and Socioeconomic Growth}

Open Science was also commonly framed as a facilitator and driver of socio-economic growth, particularly to build comparative advantages amidst global competition. This was explicitly stated by the EU who noted Open Science could be "embedded in society as a socio-economic driver", "instrumental in making science more responsive to societal and economic expectations"). G7 and Colombia also both explicitly referred to economic development and socioeconomic growth (respectively) as goals of, and outcomes from their Open Science vision. This is also evidenced by the market-based language of optimising, improving the efficiency (Japan, Elsevier, EOSC, Chile), reducing costs, and ensuring a "return on investment" (African OS Platform) for research, data (Chile), storage (EOSC), search, and diffusion (Elsevier) The "innovation based economy" was also noted as one of the express goals of the Mallorca Declaration, with EOSC noting that the "transition to open science [was to be seen] in the context of the Digital Single Market" strategy. The potential for Open Science to facilitate and drive innovation was also a common theme, particularly through "knowledge exploitation" (Japan) data-driven innovation (LIBER), and the "innovative potential of small-medium-enterprises" (Work Programme). Higher education institutions, such as Aalto University also appear to align, noting its commitment to open science and research goals to ensure research results "can be used as business assets to achieve benefits for society as a whole."

\section{Open Science as a response to global development challenges}

17 A few policies framed Open Science as instrumental to addressing global challenges and barriers, emphasizing the value of producing locally relevant knowledge, particularly for developing countries. Colombia claims that one of the benefits of Open Science is "the rapid and joint response to the global challenges of our time... [which] enables the participation of scientists and those interested both in local and global environments in the search for solutions to problems like those identified in the Sustainable Development Goals". The Kenyan Forum Report on Open Science in Agriculture proposes revising the set of metrics used to measure quality and create suitable metrics to track and monitor the visibility of how Open Science facilitates knowledge production, as well as rewards for researchers who use scientific knowledge to solve local problems. The OECD also cites the importance of "international collaboration" within Open Science in the interest of addressing global issues. This multilateral coordination and co-operation was also cited as having a critical role in Research \& Development programmes, particularly in the 
emerging economies of the BRIC (Brazil, Russia, India, and China) countries. We find that policies also envision Open Science as a means to address "global challenges and barriers" for knowledge economies and research institutions; issues pertaining to society at large, such as the SDGs, are fairly broad-brushed.

\section{Breaking dependency on "publish or perish" model}

Finally, Open Science is also being framed as a paradigm meant to cut the cycles of dependency to the current subscription-based journal system. The European Universities' Associations Statement on Open Science to EU institutions and National Governments recognises the need to change the current publishing system, calling for a more "transparent, cost-effective, and innovative system" that better serves the interests of the research community and research institutions. Key outcomes from the Forum Report on Open Science in Agriculture in Kenya also point to reforms in the current knowledge production system; they claim that the current rewards systems privileges job promotion and visibility of research within high-impact journals, and is not conducive to the Open Science paradigm. They point to alternative forms of incentives, such as rewarding data sharing, as opposed to just rewarding conferences and journals. Despite these calls for reform, the OpenAIRE regional policy cites that tension may nevertheless exist within the competitive "publish or perish" paradigm, even if new collaborative models are in place suggesting these paradigms will co-exist. In contrast, the EOSC Declaration, takes an economic perspective regarding the value of Open Science, which lies in its potential to reduce rent-seeking behaviour and prepare the market for innovative research services and business models.

\section{Discussion: Situating Open Science Policies in Power Imbalances}

These key policy narratives do not emerge in a vacuum. Under the premise that openness needs to be "situated" within the histories, social contexts and power structures that shape and constrain them (Hillyer, 2017), one of the main objectives of this research was to contextualize the narratives that are emerging in policies from different parts of the world. One of these contexts is the historical global inequality in scientific knowledge production and exchange systems. A growing body of literature has shown that the current academic knowledge system is unjust and uneven, as it centers and prioritizes knowledge produced by Anglo-speaking male researchers in North America and Europe and shared through international academic journals (Graham et al., 2015; Larivière, 2013; Chan, 2011, Okune, 2016; Czerniewicz, 2015; Canagarajah, 2002). This system has been built on a set of material and symbolic barriers to participation and representation, that range from a widespread lack of internet connectivity and weak digital infrastructures in developing countries, to high subscription costs that impede access to and publication in peer-reviewed journals. This system affects researchers from historically marginalized geographies and identities the most, who in the words of Leslie Chan, remain "nearinvisible and under-valued" (2011), as well as contribute to epistemicide, harming the general public's ability to acquire a more holistic understanding of the world and the issues affecting underrepresented populations (Moletsane, 2014, Hillyer, 2017; Sillitoe, 2007, Hall and Tandon, 2017). Open Science policies have been framed as a change to the 
aforementioned system, however our analysis of the data suggests that these power imbalances are rather being sustained by epistemic governance mechanisms, in three main ways:

\section{Political pressure and the risk of non-alignment}

Evidence of epistemic governance can be seen explicitly when member-states and other potential partner-nations of supranational governments, such as the European Union, multinational organizations like the OECD, or initiatives such as OpenAIRE are called upon to align with a specific set of Open Science visions and goals. This alignment is not only a product of jurisdictional commitments, but is often voluntary, as non-state actors such as publishers and university institutions, drive with these visions in order to obtain access to funding and resources. In the case of these actors, the risks of non-alignment are much larger than the loss of autonomy in the process of framing Open Science in a more contextualized manner. These risks include: loss of access to potential funding, global partnerships and membership, and an overall positive reputation in the international community. Investment in Open Science is perceived as a means to prevent innovation outflow and economic decline, and obtain the necessary competencies to remain internationally competitive. Even relatively well-resourced actors such as Japan and member states of the European Union express anxieties about being "left behind" in the growing "knowledge economies." This is especially challenging for regions with resource constraints, already facing pressure to meet foreign scientific standards to stay relevant in the international science ecosystem, while foregoing potential benefits and investment into more locally relevant research to appeal to international interests (Czerniewicz, 2015).

\section{Power imbalances embedded in infrastructure}

Open Science infrastructure is the second site of epistemic governance. These research infrastructures ubiquitously referenced as "foundational" to the implementation and execution of Open Science policies embed norms, values and dominant scientific practises within its increasingly complex and aspirationally global architecture. Currently, the funders and contributors of these research infrastructures promoted by these policies appear to be concentrated in wealthier regions of the world, raising concerns for how they will amplify the visibility of knowledge produced in these regions, and how this will affect the visibility of under-represented scholarship of the rest of the world (Graham et al., 2015). Their power is intrinsic in the ability to design the architecture of these systems, and ultimately regulate and control how information is produced, accessed, and shared. Once these architectures scale, they become increasingly complex and nearly impossible to change, with the foundational rules setting a path dependency for all other architecture built on top (Lessig, 2006; Sterne, 2012). While the policies reflects intentions of instituting collaboratively defined standards and distributed forms of technical control; it is important to critically consider who is at the table. Other media industries have found standard setting processes often impeded not by technical complexity, but unwillingness of major corporate players to cooperate, thereby-stifling-innovation and interoperability (Brooke, 2014). Major players in this ecosystem include former publisheroligopolies like Elsevier, rebranded as full-fledged "data analytics" companies via infrastructural acquisitions across the entire research production value chain. (Posada 
and Chen, 2017). Some have questioned the participation of those with fiduciary responsibility in policy-making processes whose interests are questionable given fiduciary responsibility and accountability to shareholders versus their interest to guarantee public access to knowledge.

\section{Open Science as the road to modernity}

The third site of epistemic governance is epistemologies. The emphasis on building knowledge infrastructures in Open Science also risks recentering and codifying European values in the architecture that shapes global science. We have inherited a system that already favors knowledge that is codifiable, useful and "instrumental" over knowledge(s) that cannot be easily codified and transmitted like community-based knowledge, knowledge of lived experience, or spiritual knowledge (Moletsane, 2014; Mignolo, 2012, Hall and Tandon, 2017). Decisions over what infrastructures need to be in place in order to produce Open Science, will shape what knowledges are considered legible, legitimate, worthy of visibility and eligible for quality control (Czerniewicz, 2015, Graham et al., 2015; De Sousa Santos, 2007; Windle, 2017). This immediately cedes power to institutions prepared to produce knowledge in these formats, researchers that investigate and communicate science in dominant languages such as English and Spanish, and even to citizens that align with notions of "expertise" in their citizen science practicecontributing further to epistemicide and reaffirming the knowledge paradigms used to justify social, political and economic "leadership" (Harding, 2002; Moore, 2017; Lawson, 2017, Nkoudou, 2017). This emphasis on infrastructure also suggests Open Science discourse is adopting techno-utopian ideals, reminiscent of the modernisation paradigms that posit a singular universal road to development, forcing developing countries to adapt to modernity via the transfer of knowledge, technology, and services by higher-income countries (Albornoz, 2017; Grosfoguel, 2000), and amplifying their dependency on concepts, paradigms and infrastructures produced in sites of power.

\section{Conclusion and Future Research Questions}

Building on the idea that narratives need to be contextualized and situated within particular histories, power structures and socio-political contexts, we sought to interrogate the assumption that open science is neutral, and investigate how the concepts used to define it at the policy level are shaped by those with institutional power and greater access to resources. For that reason, our analysis seeked to tap onto the ideological foundations at the core of shared narratives of openness across policies, and the impact this may have on reinforcing global inequality in the scientific and development fields.

As seen in the discussion, Open Science frames the rhetoric of openness as a vehicle to promote the need for technological change as part of an inevitable and necessary cultural shift in scientific production. While we are cognizant that infrastructures, protocols and tools are instrumental to producing and sharing science, we are pointing out the ways in which their development is mainly informed by global governance dictums and economic competition agendas, rather than by the demands and unique characteristics of the wide diversity of scientific knowledge producers and users that will eventually rely on them. The global reach of these narratives, and the technologies, standards and models these 
narratives sustain, will dictate modes of working and collaborating among those actors who can access and meet them, they also create new categories to exclude and invalidate knowledge that cannot meet this criteria, putting historically marginalized researchers and publics at further disadvantage. For this reason, above all, this study seeks to promote critical thinking about technological change about who it benefits and who may be left behind by the emergence of new trends. We hope these insights contribute to scholarship and activism that promotes more inclusive, community-grounded definitions of Open Science framed around the need for equitable knowledge ecosystems in service of a science that attends to social needs.

This research also meant to offer a preliminary overview of topics to unpack further in future research. Our findings first point at the need to follow more closely the funding mechanisms and the involved stakeholders behind the policy making process. Second, it lays the foundations for a more in depth investigation on Open Science infrastructure: the configuration of the architecture, rules of engagement, and the stakeholder experience with these platforms. And third, even though we hinted as a possible disconnect between technical solutions to Open Science and the skills and resources needed to use them, we consider a follow up research on the implementation of these practices necessary to allow us to better gauge the extent to which these narratives were built on the basis of political pressure, public demand or both. As Open Science advocates, we are interested in seeing these initiatives succeed, yet we need to stay vigilant and constantly question their ability to bring about real social and cultural change in knowledge production.

\section{BIBLIOGRAPHY}

\section{References}

Alasuutari, Pertti, \& Ali Qadir. "Imageries of the Social World in Epistemic Governance."

International Sociology 31, no. 6 (November 2016): 633-52. https://

doi.org/10.1177/0268580916662386

Albornoz, Denisse. "The Rise of Big Publishers in Development and What Is at Stake." The Knowledge GAP (blog), September 20, 2017. http://knowledgegap.org/index.php/2017/09/20/therise-of-big-publishers-in-development-what-is-at-stake/

Bartling, Sönke, \& Sascha, Friesike. (2014). “Open Science: One Term, Five Schools of Thought.” In Opening Science, 17-47. Cham: Springer International Publishing. http://

link.springer.com/10.1007/978-3-319-00026-8_2

Benford, Robert D., \& David A. Snow. "Framing Processes and Social Movements: An Overview and Assessment." Annual Review of Sociology 26, no. 1 (August 2000): 611-39. https://

doi.org/10.1146/annurev.soc.26.1.611 
Brooke, Tony. "Descriptive Metadata In The Music Industry: Why It Is Broken And How To Fix It." Journal of Digital Media Management 2, no. 3 (February 1, 2014): 263-82.

Buduru, Bogdan, \& Leslie A. Pal. "The Globalized State: Measuring and Monitoring Governance.” Edited by Pertti Alasuutari. European Journal of Cultural Studies 13, no. 4 (November 2010): 511-30. https://doi.org/10.1177/1367549410377144

Bullemore, Alberto. (2017) "LA Referencia: Implementing the OpenAIRE guidelines in Latin America." OpenAIRE Blog. Retrieved from: https://blogs.openaire.eu/?p=1020

Canagarajah, A. Suresh. (2002). A geopolitics of academic writing. University of Pittsburgh Press.

Chan, Leslie, Barbara, Kirsop, \& Subbiah, Arunachalam."Towards Open and Equitable Access to Research and Knowledge for Development." PLoS Medicine 8, no. 3 (March 29, 2011): e1001016. https://doi.org/10.1371/journal.pmed.1001016.

Czerniewic, Laura. "Confronting Inequitable Power Dynamics of Global Knowledge Production and Exchange." The Water Wheel 14, no. 5 (October 2015): 26-28.

ElSabry, ElHassan. "Who Needs Access to Research? Exploring the Societal Impact of Open Access." Revue Française Des Sciences de L'information et de La Communication, no. 11 (August 1, 2017). https://doi.org/10.4000/rfsic.3271.

Fecher, Benedikt, \& Sascha, Friesike. (2014). "Open Science: One Term, Five Schools of Thought.” In Opening Science, edited by Sönke Bartling and Sascha Friesike, 17-47. Cham: Springer International Publishing. http://link.springer.com/10.1007/978-3-319-00026-8_2.

Georgieva, Teodora Marinova. "Research Infrastructure Megaproject (RIMPS) Management in an Ecosystem Perspective Literature Review." Organization, Technology \& Management in Construction: An International Journal 4, no. 3 (December 2012): 625-41. https://doi.org/10.5592/otmcj.2012.3.6.

Graham, Mark, Stefano, De Sabbata, \& Matthew A. Zook. “Towards a Study of Information Geographies: (im)mutable Augmentations and a Mapping of the Geographies of Information: Towards a Study of Information Geographies." Geo: Geography and Environment 2, no. 1 (June 2015): 88-105. https://doi.org/10.1002/geo2.8.

Grosfoguel, Ramón. "Developmentalism, Modernity, and Dependency Theory in Latin America." Nepantla: Views from South 1, no. 2 (2000). https://www.umass.edu/legal/Benavides/ Fall2005/397U/Readings\%20Legal\%20397U/5\%20Ramon\%20Grosfoguel.pdf.

Hall, Budd L., \& Rajesh, Tandon. "Decolonization of Knowledge, Epistemicide, Participatory Research and Higher Education." Research for All 1, no. 1 (January 1, 2017): 6-19. https:// doi.org/10.18546/RFA.01.1.02.

Harding, S. "Must the Advance of Science Advance Global Inequality?" The International Studies Review, 4, no. 2 (Summer 2002). http://www.ingentaconnect.com/content/bpl/ misr/2002/00000004/00000002/art00265.

Herb, Ulrich, \& Joachim, Schöpfel. (2018). “Open Divide Emerges As Open Access Unfolds,” April. https://doi.org/10.5281/zenodo.1206390.

Howarth, David. "Power, Discourse, and Policy: Articulating a Hegemony Approach to Critical Policy Studies." Critical Policy Studies 3, no. 3-4 (April 28, 2010): 309-35. https:// doi.org/10.1080/19460171003619725.

Hulst, Merlijn van, \& Dvora, Yanow. “From Policy 'Frames' to ‘Framing': Theorizing a More Dynamic, Political Approach.” The American Review of Public Administration 46, no. 1 (January 2016): 92-112. https://doi.org/10.1177/0275074014533142. 
Kapczynski, Amy. (2008). “The Access to Knowledge Mobilization and the New Politics of Intellectual Property.” The Yale Law Journal 117: 804-85.

Larivière, V, C Ni, Y Gringras, B Cronin, and C.R. Sugimoto. (2013). “Global Gender Disparities in Science." Nature News 504, no. 7479: 211.

Lessig, Lawrence. (2006). Code. Version 2.0. New York: Basic Books.

Lawson, Stuart. (2017). The politics of open access: Chapter 1. PhD thesis draft version $0.1<\mathrm{http}: / /$ stuartlawson.org/phd/>

Marsden, David. "Local Science vs Global Science: Approaches to Indigenous Knowledge in International Development-Edited by Paul Sillitoe." Journal of the Royal Anthropological Institute 13, no. 4 (December 2007): 1028-29. https://doi.org/10.1111/j.1467-9655.2007.00472_5.x.

Mayer, Katja. (2015). “From Science 2.0 to Open Science-Turning Rhetoric into Action?" STCSN-ELetter 3, no. 1. http://stcsn.ieee.net/e-letter/stcsn-e-letter-vol-3-no-1/from-science-2-0-to-openscience.

Mignolo, Walter. (2012). Local Histories/global Designs: Coloniality, Subaltern Knowledges, and Border Thinking. Princeton, NJ: Princeton University Press. http://site.ebrary.com/id/10590910.

Moletsane, Relebohile. (2015). "Whose Knowledge Is It? Towards Reordering Knowledge Production and Dissemination in the Global South." Educational Research for Social Change (ERSC) 4, no. 2 https://search.proquest.com/openview/251739b3f7ac2d823014df5ebf4f3e66/1?pqorigsite $=$ gscholar\&cbl $=2037364$.

Moore, S. A. (2017). A genealogy of open access: negotiations between openness and access to research/ Une généalogie de l'open access: négociations entre l'ouverture et l'accès à la recherche.

Neylon, Cameron. (2017). “Openness in Scholarship: A Return to Core Values?” Stand Alone, 6-17. https://doi.org/10.3233/978-1-61499-769-6-6.

Nielsen, M. (2013). Reinventing Discovery: The New Era of Networked Science (Reprint edition). Princeton University Press.

Nkoudou Mboa, Thomas. (2017). Year of publication, "he (Unconscious?) Neocolonial Face of Open Access: Dynamics of Power in Francophone African Universities", presentation at OpenCon, Berlin, 2017. Retrieved from <https://www.slideshare.net/RightToResearch/the-unconsciousneocolonial-face-of-open-access-dynamics-of-power-in-francophone-african-universitiesthomas-mboa-opencon-2017>

Okune, Angela, Becky, Hillyer, Denisse, Albornoz, Sambuli, Nanjira, \& Leslie, Chan. "Tackling Inequities in Global Scientific Power Structures." The African Technopolitan 4, no. 1 (January 2016). https://tspace.library.utoronto.ca/handle/1807/71107

Posada, Alejandro, \& George, Chen. "Publishers Increasingly in Control of Scholarly Infrastructure and This Is Why We Should Care," September 20, 2017. http://knowledgegap.org/ index.php/sub-projects/rent-seeking-and-financialization-of-the-academic-publishing-industry/ preliminary-findings/

De Sousa Santos, Boaventura, (Ed.) (2007). Cognitive Justice in a Global World: Prudent Knowledges for a Decent Life. Graven Images. Lanham: Lexington Books.

De Sousa Santos, Boaventura. (2015). Epistemologies of the South: Justice against epistemicide. Routledge.

Schöpfel \& U. Herb (Ed.) Open Divide: Critical Studies on Open Access, 147-155. Sacramento, CA: Library Juice Press. 
Sterne, Jonathan. (2012). MP3: The Meaning of a Format. Sign, Storage, Transmission. Durham: Duke University Press.

Windle, Joe. (2017). "Hidden Features in Global Knowledge Production: (re)positioning Theory and Practice in Academic Writing." Revista Brasileira de Linguística Aplicada 17, no. 2: 355-78.

\section{NOTES}

1. Our search for policies took place from October 2017-March 2018. While we attempted to be holistic in our search, we can't necessarily guarantee that this was an exhaustive and comprehensive list.

2. We initially intended to focus on Open Science policies only, but found that Open Science is a concept that has been incorporated into Open Access, Open Data, Open Innovation and Open Government policies and programs. Restricting our analysis to policies that explicitly used the term "Open Science" was a methodological decision that limited our research in terms of understanding of programs and policies that practice open science, but have not adopted the same language.

3. The data was collected in this document. The data collection and analysis process was led entirely by volunteers who devoted their resources to this project. The experience of working with volunteers, brought to light some of the limitations of open citizen science, such as limited time commitment, expertise and resources, as well as the benefits of peer-to-peer learning and the enriching experience of collaborative knowledge production.

4. A list of stakeholders and their associated policies can be found in the Index.

5. This could be influenced by the language limitations; our team searched for documents only in English, Spanish, and French

\section{ABSTRACTS}

Given that "Open Science" is becoming a popular policy object around the world, this study sought to identify key narratives about Open Science in policy, and critically examine the extent to which they are sustaining or strengthening multi-layered domination and inequality schemes that pre-exist in scientific knowledge production. To do so, we conducted a content analysis of Open Science policies stemming from Europe, North America, Latin America, Asia and Africa to understand which narratives about Open Science policies are produced, reproduced and by whom; and in turn, whose interests may be neglected in this process. We found that Open Science policies, mostly stemming from Europe, frame "openness" as a vehicle to promote technological change as part of an inevitable and necessary cultural shift to modernity in scientific production. The global reach of these narratives, and the technologies, standards and models these narratives sustain, are dictating modes of working and collaborating among those who can access them, and creating new categories of exclusion that invalidate knowledge that cannot meet this criteria, putting historically marginalized researchers and publics at further disadvantage. 
INDEX

Keywords: Open science, research infrastructure, epistemic governance, framing theory, policy analysis

\section{AUTHORS}

DENISSE ALBORNOZ

The Knowledge G.A.P., Peru

albornoz.denisse@gmail.com

\section{MAGGIE HUANG}

The Knowledge G.A.P., University of Toronto Scarborough, Canada maggie@cis-india.org

\section{ISSRA MARIE MARTIN}

The Knowledge G.A.P., University of Toronto Scarborough, Canada im.martin@mail.utoronto.ca

(corresponding author)

\section{MARIA MATEUS}

The Knowledge G.A.P., University of Toronto Scarborough, Canada mateus.maria0@gmail.com

(corresponding author)

\section{AICHA YASMINE TOURÉ}

The Knowledge G.A.P., University of Toronto Scarborough, Canada aichay.toure@mail.utoronto.ca

(corresponding author)

\section{LESLIE CHAN}

The Knowledge G.A.P., University of Toronto Scarborough, Canada chan@utsc.utoronto.ca

(corresponding author) 


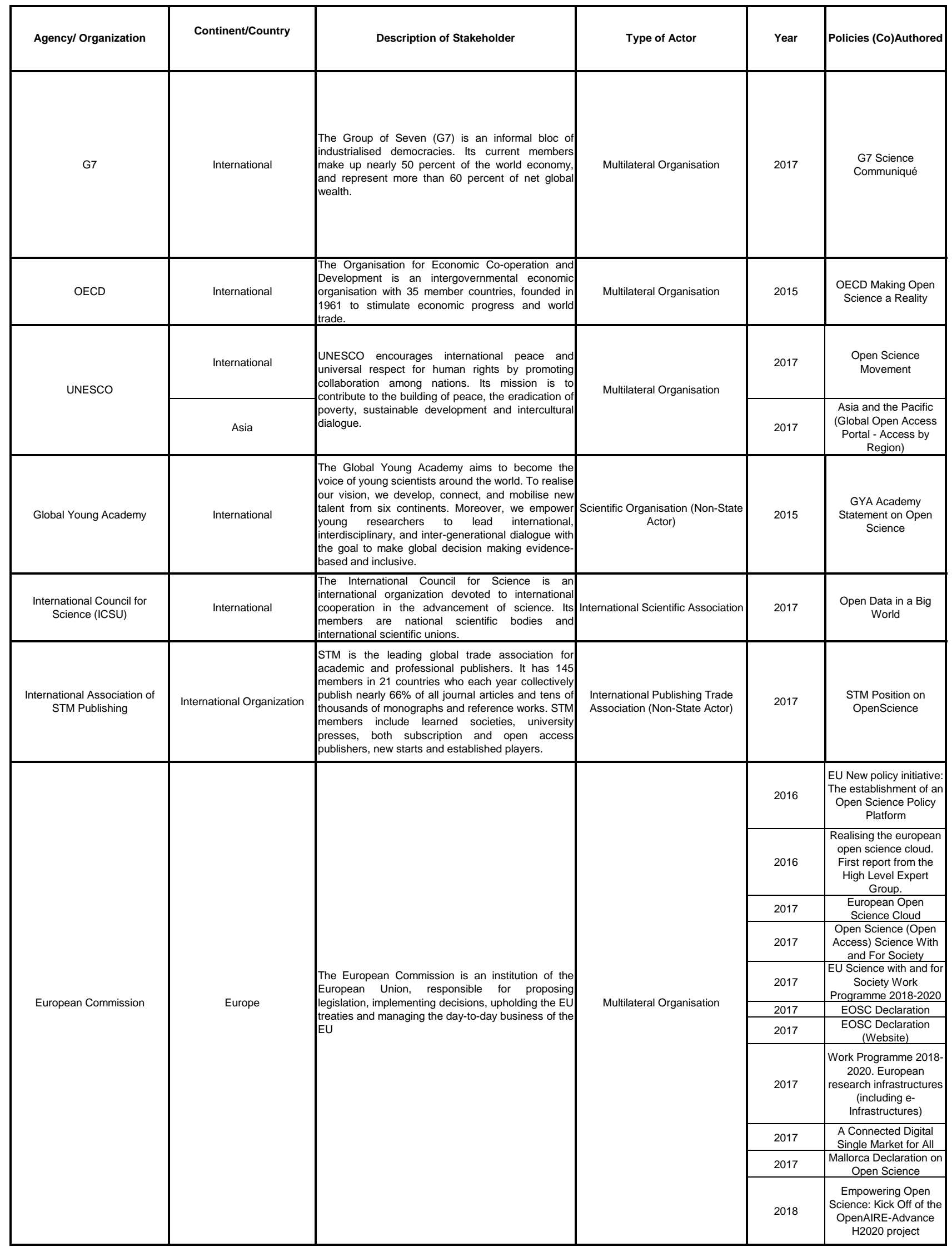




\begin{tabular}{|c|c|c|c|c|c|}
\hline Agency/ Organization & Continent/Country & Description of Stakeholder & Type of Actor & Year & Policies (Co)Authored \\
\hline La Referencia & South \& Latin America & $\begin{array}{l}\text { The Latin American Federated Network of Scientific } \\
\text { Documentation Repositories-LA Referencia was } \\
\text { officially constituted on December 2012. It is a } \\
\text { project funded by the Fund of Regional Public Goods } \\
\text { of the Inter-American Development Bank (IDB), as } \\
\text { part of the effort to consolidate the regional public } \\
\text { asset. The main purpose of LA Referencia is to build } \\
\text { a Latin American collector of scientific production for } \\
\text { storing, sharing and disseminate the scientific } \\
\text { production of Latin America. The membership of La } \\
\text { Referencia is comprised of nine partner countries } \\
\text { actively involved, represented by National } \\
\text { Organizations for Science and Technology and } \\
\text { Advanced Academic Networks from Argentina, } \\
\text { Brazil, Chile, Colombia, Ecuador, Mexico, Peru, } \\
\text { Venezuela and El Salvador. }\end{array}$ & $\begin{array}{c}\text { Multilateral Organisation (partially } \\
\text { funded by EU, and InterAmerican } \\
\text { Development Bank) }\end{array}$ & 2016 & $\begin{array}{l}\text { Infraestructura regional } \\
\text { para el acceso abierto, } \\
\text { ciencia abierta }\end{array}$ \\
\hline OpenAire Blog & Europe / Estonia & $\begin{array}{l}\text { OpenAIRE is an EC-funded initiative which aims to } \\
\text { support the Open Access policy of the European } \\
\text { Commission via a technical infrastructure. } \\
50 \text { partners make up this collaborative effort working } \\
\text { towards a common goal to bring a change in } \\
\text { realising open science for the benefit of society, } \\
\text { innovation and industry. } \\
\text { OpenAIRE currently operates an interoperable and } \\
\text { validated network of more than } 520 \text { repositories and } \\
\text { OA journals, integrating more than } 9 \text { million OA } \\
\text { publications and } 1,000 \text { datasets, with } 50,000 \\
\text { organizations and } 30,000 \text { projects from two funders. } \\
\text { It has identified over } 100,000 \text { FP7 publications from } \\
\text { about half the } 26,000 \text { FP7 projects, and offers } \\
\text { literature-data integration services. }\end{array}$ & EC-Sponsored Initiative & 2017 & $\begin{array}{l}\text { Open Science policy } \\
\text { developments in } \\
\text { Estonia }\end{array}$ \\
\hline ERA Portal Austria & Europe / Austria & $\begin{array}{l}\text { ERA Portal Austria is a knowledge-sharing platform } \\
\text { providing information on EU-related research policy } \\
\text { and its implementation in Austria and in Europe. In } \\
\text { this context it supports decision-making by providing } \\
\text { strategic intelligence. In addition, ERA Portal Austria } \\
\text { serves as a promotion platform for Austrian initiatives } \\
\text { in Europe. }\end{array}$ & State-sponsored Platform & 2015 & $\begin{array}{l}\text { ERA Portal Austria } \\
\text { Policy Brief on Open } \\
\text { Science }\end{array}$ \\
\hline $\begin{array}{l}\text { Ministry of Education and } \\
\text { Culture (Finland) }\end{array}$ & Europe / Finland & $\begin{array}{l}\text { The Ministry of Education and Culture is one of the } \\
\text { twelve ministries in Finland. It prepares laws and } \\
\text { oversees the administration of matters relating to } \\
\text { education, and culture, as well as sports and science }\end{array}$ & Government Ministry & 2017 & $\begin{array}{l}\text { Open science and } \\
\text { research roadmap } \\
\text { 2014-2017 }\end{array}$ \\
\hline $\begin{array}{l}\text { Academy of Finland (Agency of } \\
\text { MEC) }\end{array}$ & & & & 2018 & $\begin{array}{c}\text { Open science: open } \\
\text { access publishing and } \\
\text { open data } \\
\end{array}$ \\
\hline $\begin{array}{l}\text { The Ministry of Education, } \\
\text { Culture and Science (OCW) }\end{array}$ & Europe/Netherlands & $\begin{array}{l}\text { The Ministry of Education, Culture and Science } \\
\text { (OCW) is the Dutch Ministry responsible for } \\
\text { Education, Culture, Science, Research, Gender } \\
\text { equality and Communications. }\end{array}$ & Government Ministry & 2016 & $\begin{array}{l}\text { Amsterdam Call for } \\
\text { Action on Open } \\
\text { Science }\end{array}$ \\
\hline $\begin{array}{l}\text { Netherlands Organisation for } \\
\text { Scientific Research (NWO } \\
\text { Dutch: Nederlandse } \\
\text { Organisatie voor } \\
\text { Wetenschappelijk Onderzoek }\end{array}$ & Europe / Netherlands & $\begin{array}{l}\text { NWO is the national research council of the } \\
\text { Netherlands. NWO is an independent administrative } \\
\text { body under the auspices of the Dutch Ministry of } \\
\text { Education, Culture and Science. NWO funds } \\
\text { thousands of top researchers at universities and } \\
\text { institutes and steers the course of Dutch science by } \\
\text { means of subsidies and research programmes. }\end{array}$ & Government Ministry & 2017 & Open Science \\
\hline $\begin{array}{l}\text { ALLEA (All European } \\
\text { Academies) The European } \\
\text { Federation of National } \\
\text { Academies of Sciences and } \\
\text { Humanities }\end{array}$ & Europe & $\begin{array}{l}\text { All European Academies (ALLEA) is the European } \\
\text { Federation of Academies of Sciences and } \\
\text { Humanities. It was founded in } 1994 \text { and brings } \\
\text { together almost } 60 \text { Academies of Sciences and } \\
\text { Learned Societies from over } 40 \text { countries in the } \\
\text { Council of Europe region. Since April } 2012 \text { the } \\
\text { President of ALLEA is Günter Stock. ALLEA is } \\
\text { financed by annual dues from its member academies } \\
\text { and remains fully independent from political, } \\
\text { religious, commercial or ideological interests. . }\end{array}$ & Academic Association & 2012 & $\begin{array}{l}\text { Open Science for the } \\
21 \text { st century: A } \\
\text { declaration of ALL } \\
\text { European Academies }\end{array}$ \\
\hline $\begin{array}{l}\text { European University } \\
\text { Association }\end{array}$ & Europe & $\begin{array}{l}\text { The European University Association represents and } \\
\text { supports more than } 850 \text { institutions of higher } \\
\text { education in } 47 \text { countries, providing them with a } \\
\text { forum for cooperation and exchange of information } \\
\text { on higher education and research policies }\end{array}$ & University Association & 2017 & $\begin{array}{c}\text { EUA Statement on } \\
\text { Open Science to EU } \\
\text { Institutions and National } \\
\text { Governments }\end{array}$ \\
\hline
\end{tabular}




\begin{tabular}{|c|c|c|c|c|c|}
\hline Agency/ Organization & Continent/Country & Description of Stakeholder & Type of Actor & Year & Policies (Co)Authored \\
\hline Aalto University & Europe / Finland & $\begin{array}{l}\text { Aalto University, Finland is a new multidisciplinary } \\
\text { science and art community in the fields of science, } \\
\text { economics, and art and design. }\end{array}$ & University & n.d. & $\begin{array}{l}\text { Open Science and } \\
\text { Research }\end{array}$ \\
\hline $\begin{array}{l}\text { Leibniz Information Centre for } \\
\text { Science and Technology } \\
\text { University Library }\end{array}$ & Europe / Germany & $\begin{array}{l}\text { The German National Library of Science and } \\
\text { Technology (TIB) is the Leibniz Information Centre } \\
\text { for Science and Technology and University Library. } \\
\text { As the German national library of science and } \\
\text { technology, as well as architecture, chemistry, } \\
\text { information technology, mathematics and physics, it } \\
\text { provides in its specialist fields national and } \\
\text { international researchers and industry practitioners } \\
\text { and-as a University Library - students, researchers } \\
\text { and teaching staff from all faculties of Leibniz } \\
\text { Universität Hannover with literature and information } \\
\text { in both printed and electronic form. As the world's } \\
\text { largest specialised library in its subject areas, TIB } \\
\text { has outstanding collections of fundamental and } \\
\text { highly specialised literature on science and } \\
\text { technology. In order to optimise the services it offers, } \\
\text { TIB conducts applied research and development. TIB } \\
\text { is a public-law foundation of the Federal State of } \\
\text { Lower Saxony. It is a member of the Leibniz } \\
\text { Association. }\end{array}$ & University Library & 2017 & $\begin{array}{l}\text { Berlin Appeal for Open } \\
\text { Science sent to } \\
\text { decision-makers }\end{array}$ \\
\hline $\begin{array}{l}\text { LIBER: Association of } \\
\text { European Research Libraries }\end{array}$ & Europe & $\begin{array}{l}\text { LIBER represents the interests of the European } \\
\text { research libraries. The main goal of the association } \\
\text { is to establish a transnational, functioning network of } \\
\text { research libraries, in order to safeguard the cultural } \\
\text { heritage of Europe, to improve the quality of the } \\
\text { collections of the participating libraries and to render } \\
\text { the information services more efficient and customer- } \\
\text { friendly. }\end{array}$ & Library Association & 2014 & $\begin{array}{l}\text { LIBER Statement on } \\
\text { Open Science }\end{array}$ \\
\hline Universities UK & Europe / UK & $\begin{array}{l}\text { Universities UK is the representative organisation for } \\
\text { the UK's universities. Founded in } 1918 \text { our mission is } \\
\text { to be the voice of universities in the UK. }\end{array}$ & University Coalition & n.d. & $\begin{array}{c}\text { About Open Science \& } \\
\text { UUK Policy Positions }\end{array}$ \\
\hline \multirow[t]{2}{*}{ Elsevier } & \multirow[t]{2}{*}{ Europe / Netherlands } & \multirow[t]{2}{*}{$\begin{array}{l}\text { Elsevier is an information and analytics company and } \\
\text { one of the world's major providers of scientific, } \\
\text { technical, and medical information. It was established } \\
\text { in } 1880 \text { as a publishing company. It is a part of the } \\
\text { RELX Group, known until } 2015 \text { as Reed Elsevier. }\end{array}$} & \multirow[t]{2}{*}{ Academic Publisher } & 2017 & $\begin{array}{l}\text { Elsevier endorses the } \\
\text { European Open } \\
\text { Science Cloud } \\
\text { Declaration }\end{array}$ \\
\hline & & & & 2017 & $\begin{array}{c}\text { Elsevier response to } \\
\text { Draft Swedish National } \\
\text { guidelines for open } \\
\text { access to scientific } \\
\text { information } \\
\end{array}$ \\
\hline Royal Society & Europe / UK & $\begin{array}{l}\text { The President, Council and Fellows of the Royal } \\
\text { Society of London for Improving Natural Knowledge, } \\
\text { commonly known as the Royal Society, is a learned } \\
\text { society. It is the oldest national scientific institution in } \\
\text { the world. fulfils a number of roles: promoting science } \\
\text { and its benefits, recognising excellence in science, } \\
\text { supporting outstanding science, providing scientific } \\
\text { advice for policy, fostering international and global co } \\
\text { operation, education and public engagement. }\end{array}$ & Scientific Society & 2012 & $\begin{array}{l}\text { Royal Society: Open } \\
\text { Science Open } \\
\text { Enterprise }\end{array}$ \\
\hline \multirow[t]{2}{*}{$\begin{array}{c}\text { Academy of Science of South } \\
\text { Africa (ASSAf) }\end{array}$} & \multirow[t]{2}{*}{ Africa/ South Africa } & $\begin{array}{l}\text { The Academy of Science of South Africa (ASSAf) } \\
\text { was inaugurated in May 1996 by the former } \\
\text { President of South Africa and patron of the } \\
\text { Academy, Nelson Mandela. It was formed in } \\
\text { response to the need for an academy of science } \\
\text { congruent with the dawn of democracy in South } \\
\text { Africa-activist in its mission of using science for the } \\
\text { benefit of society. The mandate of the Academy } \\
\text { encompasses all fields of scientific enquiry and it } \\
\text { includes the full diversity of South Africa's } \\
\text { distinguished scientists. The Parliament of South } \\
\text { Africa passed the Academy of Science of South } \\
\text { Africa Act, Act } 67 \text { of 2001, which came into operation } \\
\text { in May 2002. }\end{array}$ & \multirow[t]{2}{*}{$\begin{array}{c}\text { Academic } \\
\text { Association/Government }\end{array}$} & 2017 & $\begin{array}{c}\text { African Open Science } \\
\text { Platform }\end{array}$ \\
\hline & & $\begin{array}{l}\text { ASSAf is the official national Academy of Science of } \\
\text { South Africa and represents the country in the } \\
\text { international community of science academies. }\end{array}$ & & 2016 & $\begin{array}{l}\text { Report on the African } \\
\text { Open Science Platform }\end{array}$ \\
\hline
\end{tabular}




\begin{tabular}{|c|c|c|c|c|c|}
\hline Agency/Organization & Continent/Country & Description of Stakeholder & Type of Actor & Year & Policies (Co)Authored \\
\hline \multirow[t]{3}{*}{$\begin{array}{l}\text { Committee on Data of the } \\
\text { International Council for } \\
\text { Science (CODATA) }\end{array}$} & \multirow[t]{3}{*}{ Africa / Botswana } & \multirow[t]{3}{*}{$\begin{array}{l}\text { CODATA is the Committee on Data of the } \\
\text { International Council for Science (ICSU). CODATA } \\
\text { exists to promote global collaboration to improve the } \\
\text { availability and usability of data for all areas of } \\
\text { research. CODATA supports the principle that data } \\
\text { produced by research and susceptible to be used for } \\
\text { research should be as open as possible and as } \\
\text { closed as necessary. CODATA works also to } \\
\text { advance the interoperability and the usability of such } \\
\text { data: research data should be intelligently open or } \\
\text { FAIR. By promoting the policy, technological and } \\
\text { cultural changes that are essential to make research } \\
\text { data more widely available and more usable, } \\
\text { CODATA helps advance ICSU's mission of } \\
\text { strengthening international science for the benefit of } \\
\text { society. }\end{array}$} & \multirow[t]{3}{*}{$\begin{array}{l}\text { Scientific Association } \\
\quad \text { (International) }\end{array}$} & 2017 & $\begin{array}{l}\text { Bostwana National } \\
\text { Forum on Open } \\
\text { Science }\end{array}$ \\
\hline & & & & 2017 & $\begin{array}{c}\text { A coordinated } \\
\text { framework for open } \\
\text { data and open science } \\
\text { in Botswana }\end{array}$ \\
\hline & & & & 2016 & $\begin{array}{l}\text { Report on the African } \\
\text { Open Science Platform }\end{array}$ \\
\hline $\begin{array}{c}\text { United Nations - Food and } \\
\text { Agriculture Organization (FAO) } \\
\text { of the UN }\end{array}$ & Africa / Kenya & $\begin{array}{l}\text { UN-The Food and Agriculture Organization (FAO) } \\
\text { is specialized agency of the United Nations that } \\
\text { leads international efforts to defeat hunger. } \\
\text { Our goal is to achieve food security for all and make } \\
\text { sure that people have regular access to enough high } \\
\text { quality food to lead active, healthy lives. With over } \\
194 \text { member states, FAO works in over 130 } \\
\text { countries worldwide. We believe that everyone can } \\
\text { play a part in ending hunger. }\end{array}$ & Multilateral Organisation & 2015 & $\begin{array}{l}\text { Report on the Forum on } \\
\text { Open Data and Open } \\
\text { Science in Agriculture }\end{array}$ \\
\hline Sci-GaiA & Africa/ Senegal & $\begin{array}{l}\text { The Sci-GalA project-“Energising Scientific } \\
\text { Endeavour through Science Gateways and e- } \\
\text { Infrastructures in Africa"-is an EU Horizon 2020 } \\
\text { funded project, under the grant agreement no: } \\
654237 \text {. The project started on the 1st of May 2015 } \\
\text { and will last for } 24 \text { months. Sci-GaiA aims at creating } \\
\text { a sustainable foundation of educational materials and } \\
\text { procedures for the development and management of } \\
\text { Science Gateways and e-Infrastructures in Africa } \\
\text { and beyond. }\end{array}$ & EU Funded Project & 2016 & $\begin{array}{c}\text { Dakar Declaration of } \\
\text { Open Science in Africa }\end{array}$ \\
\hline \multirow{2}{*}{$\begin{array}{l}\text { MEXT (Ministry of Education, } \\
\text { Culture, Sports, and } \\
\text { Technology)-Japan }\end{array}$} & \multirow[t]{2}{*}{ Asia / Japan } & \multirow{2}{*}{$\begin{array}{l}\text { The Ministry of Education, Culture, Sports, Science } \\
\text { and Technology (文部科学省 Monbu-kagaku-shō), } \\
\text { also known as MEXT, Monka-shō, and formerly the } \\
\text { Ministry of Education, Science and Culture (文部省 } \\
\text { Monbu-shō), is one of the ministries of the Japanese } \\
\text { government. } \\
\text { In January 2001, the former Monbu-shō and the } \\
\text { former Science and Technology Agency (科学技術庁 } \\
\text { Kagaku-gijutsu-chō) merged to become the present } \\
\text { MEXT. }\end{array}$} & Government Ministry & 2017 & $\begin{array}{l}\text { JST Policy on Open } \\
\text { Access to Research } \\
\text { Publications and } \\
\text { Research Data } \\
\text { Management }\end{array}$ \\
\hline & & & Government Ministry & 2015 & $\begin{array}{l}\text { White Paper on } \\
\text { Science and } \\
\text { Technology } 2015\end{array}$ \\
\hline $\begin{array}{l}\text { The Expert Panel on Open } \\
\text { Science, based on Global } \\
\text { Perspectives Cabinet office, } \\
\text { Government of Japan }\end{array}$ & Asia / Japan & $\begin{array}{l}\text { The Cabinet of Japan is the executive branch of the } \\
\text { government of Japan. It consists of the Prime } \\
\text { Minister, who is appointed by the Emperor after } \\
\text { being designated by the National Diet, and up to } \\
\text { nineteen other members, called Ministers of State }\end{array}$ & Government Ministry & 2015 & $\begin{array}{l}\text { Promoting Open } \\
\text { science in Japan }\end{array}$ \\
\hline $\begin{array}{l}\text { Innovation, Science and } \\
\text { Economic Development } \\
\text { Canada }\end{array}$ & North America / Canada & $\begin{array}{l}\text { Innovation, Science and Economic Development } \\
\text { Canada, or ISED, formerly Industry Canada, is the } \\
\text { department of the Government of Canada with a } \\
\text { mandate of fostering a growing, competitive, and } \\
\text { knowledge-based Canadian economy }\end{array}$ & Government Ministry & 2016 & \begin{tabular}{|} 
Innovation, Science and \\
Economic \\
Development's Open \\
Government \\
Implementation Plan \\
(OGIP) \\
\end{tabular} \\
\hline $\begin{array}{l}\text { National Institutes of Health } \\
\qquad(\mathrm{NIH})\end{array}$ & $\begin{array}{c}\text { North America / United } \\
\text { States }\end{array}$ & $\begin{array}{l}\text { The National Institutes of Health }(\mathrm{NIH}) \text {, a part of the } \\
\text { U.S. Department of Health and Human Services, is } \\
\text { the nation's medical research agency - making } \\
\text { important discoveries that improve health and save } \\
\text { lives. }\end{array}$ & Government Ministry & 2017 & \begin{tabular}{|c|} 
National Academies \\
Launches New Study \\
on Moving "Toward an \\
Open Science \\
Enterprise" \\
\end{tabular} \\
\hline Centre for Open Science & $\begin{array}{c}\text { North America / United } \\
\text { States }\end{array}$ & $\begin{array}{l}\text { The Centre for open Science is a nonprofit } \\
\text { technology and culture change company which aims } \\
\text { to increase openness, integrity, and reproducibility of } \\
\text { research. What started as a small project is now a } \\
\text { team of more than } 50 \text { employees; we have a suite of } \\
\text { free, open products and services to support } \\
\text { researchers, journals, funders, institutions, and } \\
\text { societies; and we have established dozens of } \\
\text { collaborations with stakeholders across disciplines } \\
\text { and stakeholder communities. }\end{array}$ & Non-State Actor & 2013 & $\begin{array}{c}\text { Centre for Open } \\
\text { Science Strategic Plan }\end{array}$ \\
\hline CONICYT & South America / Chile & $\begin{array}{l}\text { CONICYT is a Chilean government agency } \\
\text { responsible for coordinating, promoting and aiding } \\
\text { scientific research in the country }\end{array}$ & Government Ministry & 2014 & $\begin{array}{l}\text { Manual de datos } \\
\text { abiertos CONICYT }\end{array}$ \\
\hline COLCIENCIAS & South America / Colombia & $\begin{array}{l}\text { The Administrative Department of Science, } \\
\text { Technology and Innovation, also known as } \\
\text { Colciencias, is a Colombian government agency that } \\
\text { supports fundamental and applied research in } \\
\text { Colombia }\end{array}$ & Government Ministry & 2017 & $\begin{array}{c}\text { Documento de Trabajo: } \\
\text { CIENCIA ABIERTA- } \\
\text { Elementos } \\
\text { conceptuales. }\end{array}$ \\
\hline
\end{tabular}




\begin{tabular}{|c|c|c|c|c|c|}
\hline Agency/ Organization & Continent/Country & Description of Stakeholder & Type of Actor & Year & Policies (Co)Authored \\
\hline \multirow[t]{2}{*}{ CONACYT } & \multirow[t]{2}{*}{ South America / Mexico } & \multirow[t]{2}{*}{$\begin{array}{l}\text { Consejo Nacional de Ciencia y Tecnología is } \\
\text { Mexico's entity in charge of the promotion of } \\
\text { scientific and technological activities, setting } \\
\text { government policies for these matters, and granting } \\
\text { scholarships for postgraduate studies }\end{array}$} & \multirow[t]{2}{*}{ Government Ministry } & 2017 & $\begin{array}{l}\text { Lineamentos Juridicos } \\
\text { de ciencia abierta }\end{array}$ \\
\hline & & & & 2017 & $\begin{array}{l}\text { Lineamentos Generales } \\
\text { de ciencia abierta }\end{array}$ \\
\hline
\end{tabular}

